\title{
CDC25B Gene
}

National Cancer Institute

\section{Source}

National Cancer Institute. CDC25B Gene. NCI Thesaurus. Code C104836.

This gene plays a role in mitotic progression. 